\title{
Mechanism for Assessing the Level of Development of the Innovative Environment of the Region
}

\author{
Elza Alekseeva ${ }^{1, *}$, and Dmitrii Kotov ${ }^{2}$ \\ ${ }^{1}$ Bashkir State University, Institute of Economics, Ufa, Russia \\ ${ }^{2}$ Ufa State Petroleum Technological University, Institute of Oil and Gas Business, Ufa, Russia
}

\begin{abstract}
The article presents the results of research on the management of cooperation in the innovative environment of the region. The research, the results of which are presented in the article, is aimed at finding a solution to the problem of assessing the level of development of the innovative environment of the region and the selection of cooperation tools to achieve the best results of innovation activity for companies. The methodological approach has been developed for assessing the level of development of the innovative environment of the region in the context of technological and regional unevenness. A mathematical toolkit is proposed to describe the process of development of the innovative environment of the region. An algorithm for managing cooperation in an innovative environment is described. The results of approbation of the methodological approach on the materials of three regions of the Russian Federation are revealed: the Belgorod region, the Republic of Bashkortostan and the Udmurt Republic. Brief recommendations for the management of cooperation in the innovative environment of the regions are formulated.
\end{abstract}

\section{Introduction}

The problem of sustainable development of regions is relevant not only for Russia. Regional economic unevenness within the country is due to different historical levels of urbanization, the availability of production capacities, the volume and quality of available resources, geographic location, cultural and environmental component and other factors. And if the resource and territorial components of the unevenness are uncontrollable, then the regional specificity in the development of technologies can affect the economic situation of the regions.

The development and introduction of innovations takes place in a special environment of innovation activity. Objectively, this innovative environment can contribute to innovation activity in different ways. When managing innovations, it becomes necessary to manage the innovative environment, therefore, the need to assess the level of development of the innovative environment to ensure better conditions. Also, in an uncontrolled innovative environment, the influence of factors, that hold down the growth rate of the level

*_Corresponding author: elza.kinzyagulova@list.ru 
of development of the innovative environment is strong. All this makes it possible to pay attention in the innovative policy of states to the formation of institutional conditions for innovation development, the creation of a regulatory and legal framework, stimulation of investment support, the provision of tax incentives and credit lines, and the creation of conditions for the foreign economic activity of innovative companies.

The question arises about an objective assessment of the level of development of the innovative environment as a whole. This will help to develop control actions. In this regard, it is proposed to consider the level of development of the innovative environment of the region $\left(\mathrm{L}_{\mathrm{ie}}\right)$ as a measure for comparing the states of the innovative environment from the point of view of the attractiveness or attraction for new companies in the perimeter of the region.

\section{Research Methodology}

The purpose of the research is to search for effective options for building a management system for the innovative environment of the region, assessing and developing it in conditions of technological and regional unevenness.

The research methodology is based on a systematic approach. The systems approach includes:

- studying the history of the emergence of the innovative environment, approaches to managing the innovative environment;

- linking the goals of the region with the goals of companies, operating in an innovative environment, dissecting problems and contradictions for cooperation;

- combination of elements of the innovative environment management system, assessment of the development levels of the innovative environment components;

- fixation of the management structure through a mathematical expression, describing the process of development of the innovative environment;

- determination of the functional load of the elements of the environment for fixing cooperative interrelations;

- studying the external environment of the innovative environment, existing interrelations with other environments and regions.

The content of factual material and relation to practice.

Insufficient development of the innovation development environment due to territorial and regional unevenness of development is identified as a source of problems. The place of application of the newly obtained developments is the systems for managing the innovative environment of the regions of the Russian Federation. The criteria for the truth of the result consist in the convergence of theoretical conclusions, conclusions, based on the results of approbation and the actual economic result for enterprises in the regions.

Research methods and principles.

Among the many scientific research methods, used to solve problems, it is possible to single out:

- methods of retrospective analysis and synthesis to assess the levels and rates of economic and technological development;

- method of system analysis;

- the classification method allowed to systematize the results of assessing the level of development of cooperation between the subjects of the innovative environment;

- methods of statistical analysis are applied to assess the convergence of theoretical conclusions and actual results of development;

- expert methods, normative and scenario forecasting, formal logic tools are used to carry out research, prepare hypotheses and describe the results. 
The principles of research include: the principle of integrity and consistency, the principle of objectivity, the principle of purposefulness, the principle of dynamism, the principle of determinism.

Research concept.

Leading countries of innovative development form a general tendency to manage cooperative interrelations as an integral part of their innovation policy [4, 5, 20]. Based on this and understanding, that cooperation is carried out in the environment of innovative creativity and in the presence of economic feasibility, a concept is proposed, in which the level of development of the innovative environment is determined as a result of the influence of factors. The influence of factors is determined by the mathematical expression (1):

$$
\mathrm{L}_{\mathrm{ie}}=\mathrm{L}_{\mathrm{co}} \times \mathrm{L}_{\mathrm{td}} \div \mathrm{L}_{\mathrm{ad}} \times \mathrm{L}_{\mathrm{f}}
$$

where $\mathrm{L}_{\mathrm{ie}}$ is the relative comparative level of development of the innovative environment, conventional units;

$\mathrm{L}_{c o}$ is comparative level of cooperation (the strength of cooperation interrelations), conventional units;

$\mathrm{L}_{\mathrm{f}}$ is comparative level of availability of economic resources, conventional units;

$\mathrm{L}_{\mathrm{ad}}$ is comparative level of administrative, political, social and other barriers, conventional units;

$\mathrm{L}_{\mathrm{td}}$ is comparative level of technological development of companies, parties of the innovative environment, conventional units.

The units of measurement of indicators, included in the relative comparative level of development of the innovative environment $\left(\mathrm{L}_{\mathrm{ie}}\right)$ are different, in this regard, a scale for assessing each of the indicators is established in the range from 1 to 10 relative to the maximum value of each of the indicators.

At the same time, the values of the integral calculated indicator are estimated in the range from the minimum $(0.01)$, when the directly proportional indicators are maximum, and the inversely proportional indicators are minimal, to the maximum (100), when the directly proportional indicators are minimal, and the inversely proportional indicators are maximum.

\section{Findings}

To assess cooperation as a component of the level of development of the innovative environment, a methodology for calculating the indicator "Comparative level of cooperation (the strength of cooperation interrelations)" was developed.

Due to the fact, that the content and principles of management impacts on cooperative interrelations are poorly developed, it is proposed to at least fix the parameters, by which the choice of the form of cooperation and partners will be made, based on goal setting and the concept of strategic development of the region. This will ensure the advanced growth of the level of development of the innovative environment as a whole, in connection with the building of cooperative relations.

One of the main tool of Russia's innovation policy is the National Technology Initiative (NTI). Experts call NTI the driver of the regional economy, and within the framework of this concept, the regions of Russia are invited to introduce the Regional NTI standard. The regional standard will make it possible to focus the attention of the regions on those unique competencies, that they are able to implement in the NTI markets.

According to the methodological recommendations on the tools for the development and support of NTI projects in the region (March 2019), it is necessary to take steps to determine the specifics of the region, to determine the strategy of focusing on the NTI 
markets, which can be chosen in accordance with the priority: "Leadership in all NTI markets", "Focus on one NTI market", "Focus on several NTI markets".

It is proposed to build the required level and format of cooperation in the region on the basis of the selected strategies. This approach is due to the interrelation between the selected NTI markets, their development in the region, which characterizes a certain technological and innovative direction of development.

To determine the current and achieve the required level of cooperation, it is necessary to assess the level of cooperation in the region, according to the format in Table 1 by open data on the state of the innovation sphere of the region and on the basis of statistical data. Depending on the selected priority for the development of the region, the assessment of the level of cooperation should be made, according to the corresponding column 4, 5 or 6 of Table 1. By the specified parameter (column 2), the presence or absence (column 3) of forms and methods of cooperation, characteristic of the selected priority (column 4, 5, 6), is estimated in conventional units.

Table 1. Forms and methods for increasing the level of cooperation in the innovative environment of the region*

\begin{tabular}{|c|c|c|c|c|c|}
\hline \multirow[b]{2}{*}{ No. } & \multirow{2}{*}{$\begin{array}{l}\text { Parameters for } \\
\text { assessing the level of } \\
\text { cooperation }\end{array}$} & \multirow{2}{*}{$\begin{array}{l}\text { Ratin } \\
\text { g } \\
\text { scale } \\
\text { (conv } \\
\text { ention } \\
\text { al } \\
\text { units) }\end{array}$} & \multicolumn{3}{|c|}{$\begin{array}{c}\text { Priority for the development of the region (Strategies for } \\
\text { focusing on the NTI markets) }\end{array}$} \\
\hline & & & $\begin{array}{l}\text { Leadership in } \\
\text { one NTI market }\end{array}$ & $\begin{array}{l}\text { Leadership in } \\
\text { several NTI } \\
\text { markets }\end{array}$ & $\begin{array}{l}\text { Leadership in } \\
\text { all NTI } \\
\text { markets }\end{array}$ \\
\hline 1 & 2 & 3 & 4 & 5 & 6 \\
\hline 1 & $\begin{array}{c}\text { Joint research and } \\
\text { development }\end{array}$ & $\begin{array}{c}2- \\
\text { yes } \\
1-\text { no }\end{array}$ & $\begin{array}{c}\text { Support is } \\
\text { focused on one } \\
\text { area of research }\end{array}$ & $\begin{array}{l}\text { Interdisciplinary } \\
\text { research }\end{array}$ & $\begin{array}{l}\text { Interdisciplinar } \\
\text { y research }\end{array}$ \\
\hline 2 & $\begin{array}{l}\text { Cooperation building } \\
\text { territory }\end{array}$ & $\begin{array}{l}1-\text { yes } \\
0-\text { no }\end{array}$ & Within the region & $\begin{array}{l}\text { Both within and } \\
\text { outside the region }\end{array}$ & $\begin{array}{l}\text { Outside the } \\
\text { region }\end{array}$ \\
\hline 3 & Cooperation form & $\begin{array}{l}1-\text { yes } \\
0-\text { no }\end{array}$ & $\begin{array}{c}\text { Building a } \\
\text { technological } \\
\text { production chain } \\
\text { in the selected } \\
\text { NTI market } \\
\text { within the region. } \\
\text { Attracting third- } \\
\text { party companies } \\
\text { to the region. }\end{array}$ & $\begin{array}{l}\text { Mixed form. It is } \\
\text { possible to build } \\
\text { technological } \\
\text { chains within the } \\
\text { region and / or } \\
\text { incorporate in } \\
\text { technological } \\
\text { chains outside the } \\
\text { region, depending } \\
\text { on the chosen } \\
\text { business segment, } \\
\text { potential and } \\
\text { opportunities. }\end{array}$ & $\begin{array}{c}\text { Incorporation } \\
\text { in } \\
\text { technological } \\
\text { chains of large } \\
\text { companies } \\
\text { outside the } \\
\text { region. } \\
\text { Depending on } \\
\text { the potential } \\
\text { and resources } \\
\text { of companies, } \\
\text { it is possible to } \\
\text { concentrate the } \\
\text { technological } \\
\text { chain of one of } \\
\text { the markets } \\
\text { within the } \\
\text { region. }\end{array}$ \\
\hline 4 & $\begin{array}{l}\text { The presence of major } \\
\text { players (leading } \\
\text { companies) in the NTI } \\
\text { market within the }\end{array}$ & $\begin{array}{l}1-\text { yes } \\
0-\text { no }\end{array}$ & $\begin{array}{l}\text { Present } \\
\text { (required) }\end{array}$ & $\begin{array}{c}\text { Present } \\
\text { (recommended) }\end{array}$ & $\begin{array}{l}\text { Present, but } \\
\text { not necessary }\end{array}$ \\
\hline
\end{tabular}




\begin{tabular}{|c|c|c|c|c|c|}
\hline & region & & & & \\
\hline 5 & $\begin{array}{c}\text { Selecting a } \\
\text { specialization (niche) } \\
\text { in the NTI market }\end{array}$ & $\begin{array}{l}1-\text { yes } \\
0-\text { no }\end{array}$ & $\begin{array}{l}\text { All niches are } \\
\text { selected. The } \\
\text { maximum } \\
\text { coverage of all } \\
\text { niches in the } \\
\text { selected NTI } \\
\text { market is } \\
\text { recommended }\end{array}$ & $\begin{array}{l}\text { Niches in the } \\
\text { markets are } \\
\text { selected. It is } \\
\text { recommended to } \\
\text { determine the } \\
\text { specialization in } \\
\text { the selected NTI } \\
\text { markets (to fill } \\
\text { niches). }\end{array}$ & $\begin{array}{l}\text { Niches in the } \\
\text { markets are } \\
\text { selected. It is } \\
\text { necessary to } \\
\text { determine the } \\
\text { specialization } \\
\text { in the selected } \\
\text { NTI markets } \\
\text { (to fill niches). }\end{array}$ \\
\hline 6 & $\begin{array}{c}\text { Cooperation of } \\
\text { universities with } \\
\text { business in terms of } \\
\text { personnel training }\end{array}$ & $\begin{array}{l}1-\text { yes } \\
0-\text { no }\end{array}$ & $\begin{array}{l}\text { Implemented } \\
\text { with a focus on } \\
\text { the } \\
\text { corresponding } \\
\text { NTI market }\end{array}$ & $\begin{array}{l}\text { Implemented in } \\
\text { the areas of } \\
\text { technological } \\
\text { development } \\
\text { (selected by the } \\
\text { NTI markets) }\end{array}$ & $\begin{array}{l}\text { Implemented } \\
\text { in all areas of } \\
\text { technological } \\
\text { development }\end{array}$ \\
\hline 7 & $\begin{array}{l}\text { Determination of } \\
\text { standards, norms in } \\
\text { the NTI market }\end{array}$ & $\begin{array}{l}1-\text { yes } \\
0-\text { no }\end{array}$ & $\begin{array}{l}\text { It is possible to } \\
\text { develop and set } \\
\text { standards in the } \\
\text { selected market }\end{array}$ & $\begin{array}{l}\text { It is possible to } \\
\text { take part in the } \\
\text { development of } \\
\text { standards if there } \\
\text { are large leading } \\
\text { companies in the } \\
\text { region in the } \\
\text { selected markets }\end{array}$ & $\begin{array}{l}\text { Most likely, it } \\
\text { is necessary to } \\
\text { adapt to the } \\
\text { developed } \\
\text { standards in } \\
\text { the NTI } \\
\text { markets }\end{array}$ \\
\hline 8 & $\begin{array}{l}\text { Availability of } \\
\text { innovation } \\
\text { infrastructure } \\
\text { facilities }\end{array}$ & $\begin{array}{l}1-\text { yes } \\
0-\text { no }\end{array}$ & $\begin{array}{l}\text { Infrastructure } \\
\text { facilities are } \\
\text { available and are } \\
\text { aimed at } \\
\text { maintaining the } \\
\text { operation of one } \\
\text { NTI market. It is } \\
\text { recommended to } \\
\text { involve third- } \\
\text { party companies } \\
\text { (outside the } \\
\text { region) in the use } \\
\text { of objects or } \\
\text { placement in } \\
\text { them. }\end{array}$ & $\begin{array}{c}\text { Balanced } \\
\text { availability of } \\
\text { infrastructure } \\
\text { facilities for } \\
\text { selected NTI } \\
\text { markets, } \\
\text { depending on the } \\
\text { specialization and } \\
\text { needs of } \\
\text { companies in the } \\
\text { region. }\end{array}$ & $\begin{array}{c}\text { There are } \\
\text { unified } \\
\text { infrastructure } \\
\text { facilities, } \\
\text { suitable for all } \\
\text { areas of NTI } \\
\text { and / or the use } \\
\text { of } \\
\text { infrastructure } \\
\text { facilities from } \\
\text { other regions. }\end{array}$ \\
\hline 9 & $\begin{array}{l}\text { Availability of "entry } \\
\text { points" to NTI in } \\
\text { infrastructure } \\
\text { facilities. } \\
\text { Organization of } \\
\text { consulting by ways of } \\
\text { cooperation with NTI }\end{array}$ & $\begin{array}{l}1-\text { yes } \\
0-\text { no }\end{array}$ & Yes & Yes & Yes \\
\hline
\end{tabular}

* Developed by the authors based on [14]

The comparative level of cooperation (the strength of cooperation interrelations) is determined by the number of parameters, corresponding to the current situation in the region. The minimum total amount can be 1 , and the maximum 10 .

The indicator "Comparative level of availability of financial resources" $\left(\mathrm{L}_{\mathrm{f}}\right)$ is determined through the key rate of the Central Bank of the country as a conditionally uniform level of availability of lending (max 12\%) [15]. Taking $12 \%$ for $100 \%$, the transition to a single unit of measurement from 1 to 10 conventional units is calculated. The lower the value, the greater the availability. 
In the context of regions, as well as countries, it is also possible to use this rate. We note, that a change in its level conditionally equally influence on the change in credit and deposit rates of the banking sector in all regions.

Next, we present the methodology for calculating the indicator "Comparative level of administrative, political, social and other barriers" ( $\left.\mathrm{L}_{\mathrm{ad}}\right)$. It is assessed on the basis of the National Rating of the Investment Climate in the Subjects of the Russian Federation (ASI). In favor of choosing this rating, the used calculation methodology is layed, taking into account the results of surveys and expert assessment, which is closer to practical realities. The maximum score in the rating is 85 ( 85 constituent entities of the Russian Federation and places in the rating). Taking 85 points for 10 conventional units, the transition to a single unit of measurement from 1 to 10 conventional units is calculated.

The comparative level of technological development of companies, parties of the innovative environment $\left(\mathrm{L}_{\mathrm{td}}\right)$ is determined in accordance with the stage of innovation development (Table 2).

Table 2. Assessment of the comparative level of technological development*

\begin{tabular}{|c|c|c|}
\hline $\begin{array}{c}\text { Innovation development } \\
\text { stage }\end{array}$ & $\begin{array}{c}\text { Assessment of the level } \\
\text { of technology } \\
\text { development }\end{array}$ & Characteristics of the stages \\
\hline No innovations & 1 & Innovations are not created \\
\hline Creation of innovation & 2 & Research and development \\
\hline $\begin{array}{c}\text { Introduction of } \\
\text { innovation }\end{array}$ & 4 & Pilot testing and first sales \\
\hline Sales growth & 6 & Taking on a market \\
\hline Maturity & 8 & Mass consumption \\
\hline Downfall & 10 & $\begin{array}{c}\text { Obsolescence and replacement of } \\
\text { innovation }\end{array}$ \\
\hline
\end{tabular}

*Developed by the author based on [7, 18]

The level of technology development corresponds to a scale from 1 to 10 conventional units, moreover, 1 conventional unit means the lack of innovative activity of the company, which does not meet the purposes of the research. In this regard, these companies are not considered.

The values of assessing the level of development of the innovative environment are interpreted in Table 3.

Table 3. Definition of the level of development of the innovative environment in accordance with the assessment scale*

\begin{tabular}{|c|c|c|}
\hline $\begin{array}{c}\text { Scale } \\
\text { (conventional } \\
\text { units) }\end{array}$ & $\begin{array}{c}\text { Characteristics of } \\
\text { the level of } \\
\text { development of the } \\
\text { innovative } \\
\text { environment Lie }\end{array}$ & Comments \\
\hline $0.01-0.9$ & Low & $\begin{array}{c}\text { A very low level of development of the innovative } \\
\text { environment requires comprehensive measures to increase } \\
\text { the level of all indicators, included in the integral indicator }\end{array}$ \\
\hline $1-20$ & Below the average & $\begin{array}{c}\text { The below average level implies the impact, first of all, on } \\
\text { the main financial and economic indicators of the level of } \\
\text { development of the innovative environment, and secondly, } \\
\text { on the level of cooperation }\end{array}$ \\
\hline $21-40$ & Average & $\begin{array}{c}\text { The average level implies the use of mainly non-financial } \\
\text { support measures, including an increase in the level of } \\
\text { technological development and cooperation }\end{array}$ \\
\hline $41-60$ & Above average & For the above average level, it is recommended to direct \\
\hline
\end{tabular}




\begin{tabular}{|c|c|c|}
\hline & & management impacts to increase the level of cooperation \\
\hline $61-80$ & High & $\begin{array}{c}\text { With a high level of development of the innovative } \\
\text { environment, it is recommended to direct management } \\
\text { impacts to maintain the achieved positions }\end{array}$ \\
\hline $81-100$ & Very high & $\begin{array}{c}\text { The reference level of development of the innovative } \\
\text { environment }\end{array}$ \\
\hline
\end{tabular}

* Developed by the author based on [2]

As a result, the mathematical expression reveals the result of management impacts to ensure the advanced growth of the level of development of the innovative environment. This allows to assess the influence of the level of cooperation on the level of development of the innovative environment as a whole and the opportunity to manage them.

To ensure an agreed level of both cooperation in the innovative environment and competition, it is proposed to build the management of the innovative environment, according to an algorithm, that includes a number of sequential steps for selecting the forms of cooperation.

The implementation of the proposed algorithm will justify and agree on strategic plans for interaction in the innovative environment at the regional level (Figure 1).

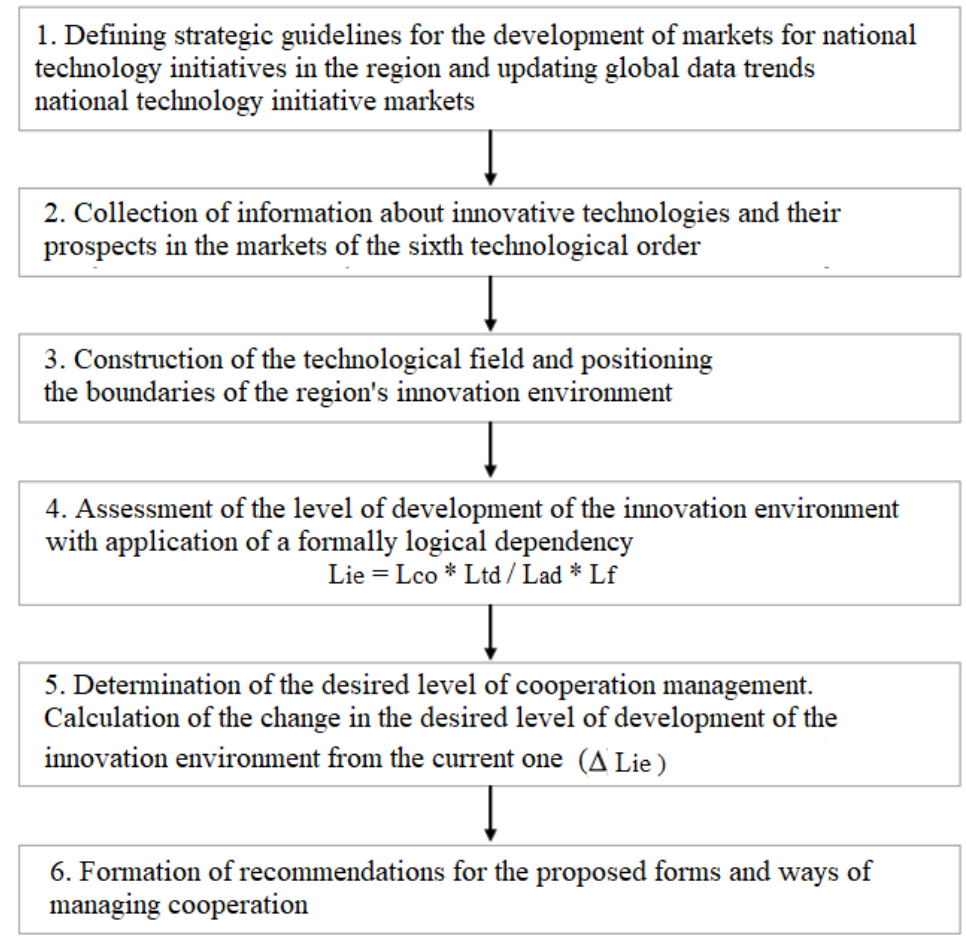

Fig. 1. An algorithm for managing cooperation in an innovative environment*

* Developed by the author based on [2, 3]

Step 1. The analysis of strategic regulatory documents of the Russian Federation, as well as documents of strategic planning of the region in order to determine the strategic priorities for the development of NTI, based on the specifics of the region.

Step 2. The analysis of data on technological trends of the selected one or several NTI markets, technologies, leading companies, Russian companies, developing and introducing innovations is carried out. It is also necessary to analyze publications of scientific research, analytical reviews, etc. 
Step 3. Technological field is an area of a technological trend within the dominant technological paradigm, which includes alternative technologies, competing with each other, emerging and developing at a rate, proceeding from the prevailing influence of factors of the innovative environment, and competing with each other [16].

Areas of trends, key technologies are determined in accordance with the strategy of focusing on the NTI markets. The leaders and the concentration of innovative activity around them are reflected according to the following criteria:

- stage of innovation development (development, introduction, first sales, taking on a market, mass consumption);

- availability of investments, search for an investor;

- recent results of development, testing or implementation of technology;

- number of partners (cooperation ties);

- availability of consumers;

- sales volume (if consumers are available).

Step 4. Assessment of the level of development of the innovative environment using formula (1).

Step 5. Determination of the desired level of cooperation management is carried out depending on which tools for supporting cooperation have already been created in the region (according to Table 1), and which of them need to be created for the development of an innovative environment.

Step 6. The implementation of the cooperation management algorithm will lead to a reasoned choice of the path of development of the innovative environment of the region, which, in turn, will affect the growth of the level of technological development and the maximization of the economic results of companies and the region as a whole.

For the purpose of checking the convergence of theoretical and practical results of the dissertation research, the developments on information arrays were tested, that characterize the activities of regions, that are leading or have the potential for leadership in the NTI markets.

The practice of using tools for assessing and managing the development of the innovative environment.

The results of calculating indicators by the formula 1 for the Belgorod region, the Republic of Bashkortostan and the Udmurt Republic are presented in Table 4.

Table 4. The results of calculating the integrated indicator for assessing the level of development of the innovative environment $\left(\mathrm{L}_{\mathrm{ie}}\right)^{*}$

\begin{tabular}{|c|c|c|c|}
\hline Indicator & $\begin{array}{c}\text { The value of the } \\
\text { indicator of the } \\
\text { Belgorod region } \\
\text { (conventional } \\
\text { units) }\end{array}$ & $\begin{array}{c}\text { The value of the } \\
\text { indicator of the } \\
\text { Republic of } \\
\text { Bashkortostan } \\
\text { (conventional } \\
\text { units) }\end{array}$ & $\begin{array}{c}\text { The value of the } \\
\text { indicator of the } \\
\text { Udmurt Republic } \\
\text { (conventional units) }\end{array}$ \\
\hline $\begin{array}{c}\text { Comparative level of } \\
\text { cooperation (the strength of } \\
\text { cooperation interrelations) } \\
\text { (Lco) }\end{array}$ & 7 & 6 & 4 \\
\hline $\begin{array}{c}\text { Comparative level of } \\
\text { availability of economic } \\
\text { resources (Lf) }\end{array}$ & 1.29 & 2.71 & 3.41 \\
\hline
\end{tabular}




\begin{tabular}{|c|c|c|c|}
\hline $\begin{array}{c}\text { Comparative level of } \\
\text { administrative, political, } \\
\text { social and other barriers (Lad) }\end{array}$ & 5.21 & 5.21 & 5.21 \\
\hline $\begin{array}{c}\text { Comparative level of } \\
\text { technological development of } \\
\text { companies, parties of the } \\
\text { innovative environment (Ld) }\end{array}$ & 4 & 3 & 2 \\
\hline
\end{tabular}

* Developed by the author based on $[2,3]$

The integrated indicator of the level of development of the innovative environment $\left(\mathrm{L}_{\mathrm{ie}}\right)$ of the Belgorod region was 4.17. According to the calculation of the current level of cooperation in the innovative environment of the Belgorod region, a value of 7 conventional units was obtained out of the maximum possible 10, which means, that the potential of cooperation management is not fully used.

Parameters, by which it is possible to improve the assessment of the level: cooperation of universities with business in terms of personnel training.

Also, the Belgorod region is represented by the largest agricultural holdings, small business start-up projects, and private farmers. In this regard, there is a potential for building a technological production chain of the agro-industrial sector in the region in various segments of the Foodnet market.

The integrated indicators of the Republic of Bashkortostan and the Udmurt Republic are equal to 1.27 and 0.57 conventional units, respectively.

The value of the current level of cooperation in the innovative environment of the Republic of Bashkortostan is 6 conventional units out of the maximum possible 10. It is possible to assume, that most regions of the Russian Federation, that are not among the top ten leaders in innovative development, will also have an indicator of the level of cooperation below 10 conventional units.

Parameters, by which it is possible to improve the assessment of the level: the selection of specialization (niche) in the NTI market, the determination of standards, norms in the NTI market.

As part of managment of cooperation in the innovative environment of the Republic of Bashkortostan, the attention should be paid to the opportunity of establishing a corporate business incubator in the field of petrochemicals. This implies building cooperation with start-ups to include them in the technological production chain, or joint development and introduction of Russian innovative technologies with large companies within or outside the region, and due to this - taking leadership positions in the EnergyNet markets.

The value of the current level of cooperation in the innovative environment of the Udmurt Republic is 4 conventional units of the maximum possible 10 conventional units.

Parameters, by which it is possible to improve the assessment of the level: the selection of specialization (niche) in the NTI market, the determination of standards, norms in the NTI market, the creation of innovative infrastructure facilities, cooperation of universities with business in terms of personnel training.

It is proposed to direct the management of cooperation in the innovative environment of the Udmurt Republic to determine the specialization of the region in the markets of NTI Autonet, Aeronet, Technet and Energynet. This will help to concentrate the innovative activity of companies in certain market niches and to take corresponding positions.

Of course, the level of development of the innovative environment should be managed by regulating not only the indicator of the level of cooperation, but also such indicators, as the level of administrative, political, social and other barriers, the level of technological development of companies in the innovative environment. 


\section{Discussion}

The study of cooperation in his works by F. Webster [19], I.N. Gerchikova [6], K.Yu. Egiazarova [9], Yu.V. Piskulov [13], S.G. Khomich [17] and other scientists allowed to form an idea of cooperation as a tool for cooperation between companies, which is the basis of this research.

This conclusion was led by the analysis of the above works, in which various approaches to the classification of cooperation are presented: by the degree or level of the interrelation of subjects [19], by the ways of organizing cooperation [6,9], by the degree of formalization [17], by the division of labor as a key factor [13].

It is necessary to distinguish the theory of co-competition of A.M. Brandenburger and B.J. Neilbuff [12]. According to this theory, the strategy of interaction between companies is developed situationally: if necessary, methods of competition or cooperation are used. This theory is reflected in the author's methodology for managing cooperation in an innovative environment.

The methodological approach of the authors of the research to the management of cooperation in order to increase competitiveness is based on the conclusions of scientists about the types of cooperation, the reasons and risks of cooperation, the criteria for choosing a partner. At the same time, the mechanism and practical recommendations for cooperation in the works considered are actually absent.

N.V. Yakovets, S.Yu. Glazyev [7], L.M. Gokhberg [8], L.E. Mindeli, M. Castells [10], D.V. Kotov [11] dedicated their works to the innovative environment and its development.

M. Castells distinguishes the special role of the interaction of economic entities within the framework of the innovative environment, which allows to achieve a synergistic effect a feature of the innovative environment [10].

The main conclusion of the analysis of these works is the perception of integration and cooperation, the level of technological development as key components of the level of development of the innovative environment. The innovative environment, in turn, is capable of generating synergy of the activity of the subjects, included in it, which was the basis for assessing the level of development of the innovative environment $[8,11]$. All this made it possible to propose to accept cooperation of enterprises and other participants of innovation processes as a basic controlled element of the innovative environment [1].

\section{Conclusion}

The methodological approach allows to achieve the purpose of the research and propose the most effective option for building a system for managing the innovative environment of the region, assessing and developing it in conditions of technological and regional unevenness.

Recommendations for managing cooperation in the innovative environment of the regions allow influencing one of the indicators of the level of development of the innovative environment. It is necessary to comprehensively apply tools to support and increase the level of development of the innovative environment.

The research results can be useful for enterprises to select the most developed and favorable innovative environment, to create competitive technologies of a new technological paradigm and achieve high economic results. And also for scientific organizations to improve the tools of innovation policy, study and assess the influence of factors, that develop the innovative environment in the context of uneven technological development.

The results of the research are of high value for Ministries and departments, when justifying measures, aimed at developing the innovative environment of the region and 
increasing the level of technological development of innovatively active companies in order to close the gap at the technological and economic level between separate regions.

The reported study was funded by RFBR, project number 19-310-90045.

\section{References}

1. E.R. Alekseeva, D.V. Kotov, Theoretical bases and methodical matters of innovation-active organizations cooperation management under the condition of uneven technological development, Proceedings of the "New Silk Road: Business Cooperation and Prospective of Economic Development" (Atlantis Press, 2020)

2. E.R. Alekseeva, Definition of the innovative environment and the factors of its formation. Collection of materials of the XI International Scientific and Practical Conference "State and Business. Modern economic problems "(April 24-26, 2019, St. Petersburg), North-West Institute of Management RANEPA under the President of the Russian Federation, 5.S, 164 (2019)

3. E.R. Alekseeva, The value and boundaries of cooperation in an innovative environment, Topical issues of the development of the national economy: materials of the VIII Intern. correspondence course scientific-practical Conf., Perm. state nat. issled. un-t. Electron. Dan. Perm, 12 (2019). http://www.psu.ru/files/docs/science/books/sborniki/aktualnye-voprosyrazvitiya-nacionalnoj-ekonomiki.pdf

4. R. Camagni, Introduction: from the local "milieu" to innovation through cooperation networks, Innovation Networks: Spatial Perspectives, London, Belhaven, 1 (1991)

5. D. Corsaro, C. Cantu, A. Tunisini, Industrial Marketing Management 41, 780 (2012)

6. I. N. Gerchikova, Management, 4th ed., Rev. and add., 512 p. (M.: Unity-Dana, 2010)

7. 7.S.Yu. Glazyev, D.S. Lvov, G.G. Fetisov, Evolution of Techno-Economic Systems: Opportunities and Limits of Centralized Regulation, 207 p. (M., 1992).

8. L. Gokhberg et al. Developing and using indicators of emerging and enabling technologies. In: Gault F. (ed.) Handbook of Innovation Indicators and Measurement. Elgar, Cheltenham, Northampton (2013)

9. K.YU. Egiazarova, Strategy and Regulatory Mechanisms for Industrial Development 3, 239 (2011)

10. M. Castells, Information Age: Economy, Society and Culture; per. from English under scientific. ed. O. I. Shkaratana, 606 p. (Moscow: GU HSE, 2000)

11. D.V. Kotov, Assessment of the innovative development of the national economy. Topical issues of economics and management. materials of the Intern. scientific. conf. I (29), (Moscow: RIOR, 2011)

12. B.J. Neilbuff, A. Brandenburger, Co-opetition. Competitive cooperation in business, 352 p. (Moscow: Omega-L. Case, 2012) 
13. Yu. V. Piskulov, Yu. Yu. Posysaev, Yu. A. Savinov, Russian Foreign Economic Bulletin 11, 42 (2014)

14. Regional STI standard. https://nti2035.ru/docs/2019_Regstandart_NTI_methodrec.pdf

15. MFD Website "Key Rates of Central Banks". http://mfd.ru/calendar/rates/

16. J. Schumpeter, Business cycles. A Theoretical, Historical and Statistical Analysis of the Capitalist Process. New York Toronto London: McGraw-Hill Book Company, 461 p. (1939)

17. S.G. Khomich, Bulletin of St. Petersburg University. Series 8. Management 3, 135 (2014)

18. K. Schwab, The Fourth Industrial Revolution. Ed. "Eksmo", 208 p. (2016)

19. F.E. Webster, Journal of Marketing 56(1), (1992)

20. M. Westerlund, R. Rajala, J. of Business and Industrial Marketing 25(6), 435 (2010) 